\title{
ALFRED G. MEYER
}

\section{Two Worlds: Communism and Western Society}

The stated purpose of the encyclopedia being reviewed here, Marxism, Communism and Western Society: A Comparative Encyclopedia ${ }^{1}$ is to present a comprehensive comparative portrait of two worlds, one called "Communism," the other, "Western Society," including their institutions and self-images, the images they have of each other, and their entire views of the cosmos; the range of topics covered is extremely wide. ${ }^{2}$ Several aims might be fulfilled by such a work. One of them is to serve as a reference book for students of Marxism and Communist societies, especially the Soviet Union, and not for specialists only but also for anyone interested in selected aspects of these topics. On the whole, the Encyclopedia serves this purpose very well. The relevant articles tend to be competent and thorough, even though I can understand why one of the anonymous referees of this essay found them "tinged with Germanic pedantry, dry and often verbose, with a penchant for abstraction, reifications, and fine distinctions." The bibliographies, which list Western as well as Soviet works, are ample. The Encyclopedia's coverage of Marxist and Soviet philosophy, the history of the USSR, and many other aspects of life in the Communist world is often superior to any other reference works I know, despite occasional lapses into one-sided criticism or seemingly capricious interpretations. An instance of such capriciousness in my opinion is the article on "Leninism" (vol. 5, pp. 189-99) which follows an excellent biographical sketch of "Lenin" (ibid., pp. 175-88). "Leninism" turns out to be an essentially Syndicalist critique inspired primarily by the writings of Pannekoek, with a dash of Kautskian determinism stirred in for good measure. This is at best a capricious interpretation, but it seems unsuitable as an encyclopedia article. Let me hasten to point out that some of the more philosophic and sociological articles are brilliant. I would single out the article on "Dialectics" (vol. 2, pp. 405-20) in which C. D. Kernig's five-column essay on dialectical method (dialectics as a way of describing experience, as a mode of human understanding, and as a mode of being of things and relations) is followed by a much longer article by Marcuse tracing the history of dialectics in ancient philosophy, Kant, Fichte, Hegel, and Marx. Kernig's essay is one of the finest summaries of this alternative way of thinking I have ever read. I was

1. Marxism, Communism and Westem Society: A Comparative Encyclopedia, vols. 1-8, ed. C. D. Kernig (New York: Herder and Herder, 1972). Vol. 1: xxvi, 436 pp. Vol. 2: viii, 459 pp. Vol. 3: viii, 388 pp. Vol. 4: viii, 448 pp. Vol. 5: viii, 484 pp. Vol. 6: viii, 470 pp. Vol. 7: viii, $478 \mathrm{pp}$. Vol. 8: xxxiv, $413 \mathrm{pp}$.

2. The author of this review article was asked to write two contributions for the Encyclopedia. One of these articles, "Authority" (vol. 1, pp. 229-37), was printed; the other, "Democracy," was not, although the editors never troubled to communicate this to the author or to explain their reasons for rejecting it. I relate this in order to show my prior involvement with the work I am reviewing here. 
similarly impressed by his article "Proletariat" which presents a history of that class; bourgeois and socialist theories of the proletariat, with special attention to the contributions made by Hegel, von Stein, and Marx; and an essay on the breakdown of the theory of the proletariat and the implications this has for Marxism (vol. 7, pp. 50-66).

Another aim of the Encyclopedia seems to have been that of providing enlightenment to people in the socialist world wishing to learn about the "West" and seeking to do so from a Western point of view. This alone explains why the work was to be published in Russian as well as in English and German. The editors apparently operated with the expectation that the Soviet Union soon would become much more open to Western intellectual influences. How convenient it would be if at that time the "West" could be made accessible to them in encyclopedic fashion: Yet as a summary of "Western" life and experience, the Encyclopedia is less than satisfactory, as I shall seek to show below.

The "Editor's Preface" states the aim of the work to be a confrontation of two seemingly incompatible systems of thought, the clash of which, despite the allegedly greater flexibility of the West, has led to mutual lack of understanding. The Encyclopedia is to probe into all areas of disagreement, to explore the origins and structure of conflicts in thought, language, and institutions, and thus to demonstrate the obstacles standing in the way of mutual understanding. Now that the work has been completed, the editor sadly concludes that the basic differences between East and West have not been bridged; but they have at least been laid bare. Thus the ostensible aim of bridge-building has in fact turned into a demonstration of the depth of the gulf to be bridged; and in his preface as well as in his many contributions to the work the editor makes it clear that he holds the Soviet camp responsible for the remaining barriers to mutual understanding.

The standard format for every major article in the work is a confrontation of Western concepts, views, practices, institutions; and so forth, with their Marxist and/or Communist counterparts. Most articles offer some general introduction into the subject matter with which they deal, then present a survey of Western theories, interpretations, or institutions, followed by a chapter on Soviet theories, interpretations, or institutions. Most articles then close with a comparison or confrontation of Western and Soviet views. Where individual sections have been written by different authors, the final confrontation more often than not has been written by the same author who contributed the section on Soviet interpretations of the topic. There are exceptions to this pattern. In some articles Marxist theories and Soviet theories are treated separately. In at least one article, "Sino-Soviet Dispute" (vol. 7, pp. 327-36), the Soviet view is confronted not with Western interpretations, but with Chinese ones. This confrontational format works quite well in the treatment of Soviet history and a number of other topics where Western and Soviet interpretations are clearly irreconcilable. But more often the confrontation makes no sense at all. Neither "The West" nor "Communism" is a homogeneous or monolithic entity. Both are pluralistic and heterogeneous; each contains a variety of schools and conflicting patterns of behavior. To see either of them as well defined comes close to idiocy. Hence some of the articles expressly repudiate the confrontational format, as I myself did in "Authority" (vol. 1, pp. 236-37). Similarly, Iring Fetscher in "Freedom" argues that the contrast between "free" and "dictatorial" systems is untenable; 
in both systems, he writes, some freedoms are granted ; in both they are in constant jeopardy (vol. 4, p. 39). In a like vein, the author of "Renaissance" argues for a synthesis of bourgeois and Marxist interpretations of the Renaissance (vol. 7, pp. 192-98).

Based, as it sometimes is, on unrealistic assumptions, the confrontational format leads to a glossing over of the differences between Marx and Stalin and between Soviet and Chinese communism, even when the individual authors are aware of these differences and when specific articles in the Encyclopedia deal with precisely these differences. The article on "Marxism" itself, though it inevitably advances a highly controversial definition of the philosophic bases of the ideology, underscores the ambiguity of the heritage and contains thoughtful chapters on German, French, Italian, Soviet, and Chinese forms of Marxism (vol. 5, pp. 342-60). But in many other articles Marxism is simply identified with Soviet dogma. Thus, what is being criticized and confronted throughout the Encyclopedia is not really Marxism or communism but primarily Soviet society and Soviet ideology. In some of the articles Soviet ideology is contrasted with allegedly Western positions that at times are much closer to the positions taken by Marx and/or Engels. When Klaus von Beyme in "Political Science" writes that "political science is a branch of the social sciences which exists as an institution only in bourgeois societies," and that "the Marxist social sciences have until now left political theory mainly to the legalists ..." (vol. 6, p. 374), he can have meant only Soviet social science, but not Marxism, which ever since Marx has taken a keen interest in the state and in politics and has developed theoretical frameworks for such studies.

Since "Marxism" for the editors of the Encyclopedia meant primarily the Soviet Union, events, institutions, personalities, and concepts important for the study of Marxist or Communist movements elsewhere are missing from the work. While there is a relatively short article on "Mao and Maoism," one looks in vain for any treatment of $\mathrm{Li} \mathrm{Ta}$-chao, $\mathrm{Li} \mathrm{Li}$-san, Ho Chi-minh, the Long March, or the Great Leap Forward, except that other articles may contain references to them. Similarly, students of Western Marxism will miss articles on Gramsci and Lukács, to mention only two.

The intended confrontation of "Western" and "Communist" or "Marxist" views becomes even more confusing when we realize that some entire articles have been written from an essentially Marxian point of view. Thus the article on "Art" contains a section on the sociology of art ("Art III"), exhaustive in scope and masterful in its treatment of an exceedingly complex topic, in which the influence of Marxism on the entire discipline is amply acknowledged (vol. 1, pp. 207-24). Similarly, the first paragraph of "Bourgeoisie" (vol. 1, pp. 280-81) opposes Marxism-Leninism with a more sophisticated "Western" interpretation that is essentially Marxist; and the entire article makes it clear that the main conflict in theories concerning the bourgeoisie is the one between Western Marxist and Marxist-Leninist interpretations, the latter clearly hampered by dogmatic political controls.

On the whole, Marxism has made a stronger impact on this encyclopedia than, say, on the International Encyclopedia of the Social Sciences. Some articles have been contributed by self-avowed Marxists; I already have mentioned Marcuse's contribution to "Dialectics." "Capitalism," written by Maurice Dobb, is a 
straightforwardly Marxist critique of bourgeois economic theory (vol. 1, pp. 386-89). "Class," "Fascism," and several other articles acknowledge the contributions made by Marxism to our knowledge of these subjects. The confrontational purpose of the Encyclopedia obviously compelled the editors to include vast quantities of subject matter important to Marxism or to Soviet ideology, or at least controversial in the Soviet Union. Many economic terms, a large proportion of philosophic concepts and scientific fields, and historic events and social institutions have been included for this reason.

The Encyclopedia differs from the International Encyclopedia of the Social Sciences in several additional ways that are worth pointing out. Although it contains only eight volumes rather than sixteen, the Encyclopedia is much broader in scope. It includes articles on topics from natural science, such as biology, agrobiology, relativity, cosmology, genetics, and quantum mechanics, as well as topics from general philosophy - for example, principle, realism, identity, humanism, causality, formalism, agnosticism. In turn, the International Encyclopedia contains far more articles on individual social scientists and methodological concepts, such as "Factor Analysis" and "Role," as well as on psychological terms (for example, "Anxiety"). But the work being reviewed here presents a far more adequate coverage of historiography, including the major eras of human history as well as the history of ideas. Indeed, after examining the Encyclopedia, one begins to wonder why anyone would publish a social science encyclopedia which does not contain articles on any of the following topics: "Bourgeoisie," "Proletariat," "Serfdom," "Absolutism," "Art," "Byzantium," "French Revolution," "Guerilla Warfare," "Renaissance," "Reformation," "Historicism," "Periodization," or "Women."

In 1857 Charles A. Dana, who had just agreed to become editor of an encyclopedia project, the New American Cyclopedia, suggested to Karl Marx that he write a number of articles for this new venture. When Marx related this offer to Engels, the latter in an initial burst of enthusiasm suggested that he and Marx write the entire encyclopedia all by themselves (Engels's letter to Marx, April 22, 1857). In the end, what they did contribute to the work fills an entire volume in their collected works.

Something similar has happened in the case of the work under review here. It is primarily the work of German and American specialists, most (but not all) of them scholars of established reputation. All the editors are German, as is the publishing house, its branch address in New York notwithstanding. The editor in chief, C. D. Kernig, could obtain advice from a board of editorial consultants -about fifteen senior scholars in Soviet studies, half of them American. Contact with American contributors was made by a U.S. editor, Abraham Brumberg, who at that time was the USIA's top specialist on the Soviet Union. A number of German scholars functioned as specialist editors in such fields as biology, economics, history, law, literature, military science, education, philosophy and ideology, physics, politics, sociology, psychology, and religion. The list of contributors is a small Who's Who in Western studies of communism or the Soviet Union. Numerous short articles were written by the editor's staff, and it is quite remarkable that the editor in chief and one of his specialist editors themselves contributed a large number of key articles. Kernig wrote all or part of "Christi- 
anity," "Cold War," "Communism," "Consciousness," "Cultural Revolution," "Dialectics," "Diplomacy," "Equality," "Guerilla Warfare," "Higher Education," "Idealism," "Industrial Psychology," "International Relations," "Jesus Christ," "Knowledge," "Leninism," "Marxism," "New Economic Policy," "Peace," "Periodization," "Pnwer," "Proletariat," and "War." Klaus von Beyme, the editor for politics and sociology, wrote all or part of "Anarchism," "Art," "Bureaucracy," "Class," "Democracy," "Elite," "Federalism," "Intellectuals and Intelligentsia," "Interest Groups," "International Relations," "Leadership," "Parliamentary System," "Political Parties," "Political Science," "Political Systems," and "Power." Many an American scholar's mind, accustomed to specialization within narrow subfields, is likely to boggle at such breadth of erudition and might not be able to shake the suspicion that dilettantes must be at work here. Let me hasten to point out that their contributions are on a high level of scholarship; and this must be said as clearly as possible. At the same time, the Encyclopedia, by virtue of their extensive contribution, obviously carries their personal imprint, and that imprint, as I shall try to show, is highly political. Many of the unsigned shorter articles, most of them dealing with Soviet or "sovietological" terms, convey a similar ideological orientation, which is that of the Cold War. The chief contributors to this work, one might say, are the encyclopedists of anti-communism.

In a work that is truly encyclopedic in its coverage, the quality of the contributions inevitably turns out to be uneven. On one hand, I was impressed by the wealth of information in a massive article on "Buddhism" (vol. 1, pp. 295311 ), although I cannot judge its scholarly adequacy. Many of the historical and philosophical articles are wide-ranging, at times brilliant, summaries of concepts, events, interpretations, or schools. A great number of these articles fairly and soberly assess Marxist and non-Marxist contributions and discuss the problems faced by each interpretation. I would single out "Paris Commune," "Anarchism," "Absolutism," "Proletariat," and "Nationalism and Nationalities Question" as pieces which impressed me as scholarly and comprehensive; but the list could be multiplied. The article on "National-Socialism" (vol. 6, pp. 65-74), still a touchy theme in Germany, suggests that in the West the popularity of the Third Reich and its ideological links with older German traditions have been overrated, and its repressive character underrated. It stresses the differences between national-socialism and bolshevism, totally discredits the totalitarian model, rightly dwells on the administrative chaos reigning under Hitler, and fairly appraises the work on the topic done in the German Democratic Republic. On the other hand, "Political Science" (vol. 6, pp. 361-76) turns into a lucid demonstration of the state of disarray in which our discipline finds itself because of the welter of approaches and methods. It ends with appreciative words about the challenge presented by Neo-Marxism and political economy: "Of all the non-Marxist political theories only functionalism offers assumptions about society which are as far-reaching as Marxism in offering a framework for social orientation. This explains the power of fascination that these two theoretical approaches hold for younger scholars who have grown weary of the theoretically undigested accumulation of empirical material in the more traditional positivist studies" (ibid., p. 374).

In some cases, otherwise fine articles are spoiled by the political sermons 
with which they end. The essay on "Periodization," including a chapter by Kernig which asserts that the quantitative and empirical approach has done away with problems of periodization forever, is brilliant, but its ending is yet another critique of Marxism. This would be quite acceptable if the authors did not subtly suggest that Marxism is the principal school of historiography whose periodization scheme is subject to challenge. "Power" is a thoughtful survey of various meanings the word has conveyed, paying tribute to the contributions Marx and Engels made to the theory of power. But it ends with the warning that concentration of power in the contemporary world must be fought by the development of countervailing powers. These are left undefined.

Again and again, the less satisfactory articles fall down either because of their anti-Marxist preoccupation-they take insufficient cognizance of differences within Marxism, or because they shy away from a critical discussion of problem areas in Western societies. "Productive Forces" illustrates the first of these failings. The article should have been an occasion for showing the differences between Marxian and Stalinist uses of a term which is crucial to an understanding of Marxist doctrines. But it seems to accept Soviet textbook definitions, without, however, making this sufficiently clear, and then renders the term meaningless by not even discussing the functions it fulfills within the context of Soviet ideology. The resulting critique is little short of asinine. "Colonial Rule" illustrates the latter failing. The article hardly deals with the history or with different types of colonial rule but concentrates, instead, on justifications for colonialism, on criticism of Marxist-Leninist theories of colonialism, and on the effort to stretch the term so that it can be made to subsume Soviet rule over minority areas in Central Asia and other parts of the USSR. Its author appears to have been overeager to disassociate the Western world from the phenomenon of colonial rule. "Slavery" (vol. 7, pp. 336-41) mentions the importation of African slaves into North America with a ten-word phrase, but devotes a lengthy paragraph to the abolition of the institution. It is one of the few articles in which I found the bibliography too skimpy.

A disappointingly banal article on "Leadership" is rendered pointless by omitting revolutionary leadership. Its author explains this by pointing out that he does not believe Weber's concept of charisma applicable to revolutions; he thinks it should be used only in the context of religious history. As a result, since revolutionary leadership obviously is neither traditional nor rational-legal, the author does not know how to deal with it except by arguing that in every instance it is unique in its own special way, arising deus ex machina. Revolutionary leaders defy classification, hence obviously cannot be grasped by the social scientist (vol. 5, p. 155). While correctly stressing Lenin's belief in the need for revolutionary leadership, the article barely touches on the totally negative attitude Marx and Engels had toward it. In a large number of other articles, those contributors who are not specialists in the study of Marxist doctrine often polemicize against a Marx or an Engels whom they do not know sufficiently well. That is the case in this instance.

The rather shallow treatment of "Bureaucracy," representative, perhaps, of the state of organization theory a decade or two ago, stresses the rational and positive aspects of modern organization but goes lightly over its more nightmarish consequences. At the same time it misses the strong emphasis on rational 
organization contained in Lenin's writings ; it stresses, instead, his antibureaucratic views, which in my opinion is a misreading of Lenin. In short, the article is based on a positive evaluation of bureaucracy and a negative one of Lenin and therefore misunderstands both. It declares bureaucracy to be an obstacle against totalitarianism, even though its author recognizes that any dictator can make use of the bureaucracy.

A muddled definition of "Democracy" is offered by von Beyme (vol. 2, pp. 313-36). In the first pages of his article he points out that there is no definition of the term on which everyone would agree. After quoting an Italian politician who told Palmiro Togliatti that "democracy permits no adjectivization; there is only one democracy," he adds, "but this view will not hold water" (ibid., p. 314). This agnostic view is not tenable. From the time of Aristotle up to the nineteenth century, democracy was quite clearly understood to be that kind of polis or state in which the masses of the people or citizens ruled or enjoyed equal political rights. If today, in the Western world, we usually mean Aristotle's politeia when we say "democracy," if we interpret "democracy" to mean a mixed constitution like those of Venice or England, then the author should have made clear that this is a very late reinterpretation of the term-in effect, a conservative co-optation of it after the American and French revolutions had begun to make it a more acceptable concept. In short, he should have distinguished clearly between the liberal (or procedural) and the radical (or substantive) interpretations of the term, but he has not done that. For a lucid discussion of the conflict between liberal constitutionalism and radical democracy one must, instead, turn to Fetscher's article on "Freedom" (vol. 4, pp. 22-33). What von Beyme's article expresses is an unresolved ambivalence, on his part, in his appraisal of democracy. On the one hand he fears it. He cites the writings of Talmon in support of this position, and warns against the "dangerous way of interpreting the term 'democracy' which results when people begin to talk of 'true' or 'genuine' democracy" (vol. 2, p. 314). On the other hand, he pays lip service to democratic ideals and blandly asserts that the United States and the Western European states are democratic throughout, disregarding various kinds of evidence that should make him at least qualify such an assertion.

. "Equality" (vol. 3, pp. 206-15) is unsatisfactory for analogous reasons. "Imperialism" (vol. 4, pp. 211-29) begins with a forthright survey of the history of modern imperialism, of theories about it; and of the struggle against it: "Communists together with liberals and British nonconformists share the historical merit of having roused the conscience of mankind against the abuse of political and economic power as industrial society expanded in America, Africa and Asia. ... Perhaps the most important motive for the enthusiastic struggle against imperialist foreign power was the will to win back lost humanity and self-respect, even at the price of sacrificing good government" (ibid., pp. 222-23). But the authors recoil from approving this struggle entirely, arguing that "national sovereignty cannot provide the whole answer to imperialism." Yet, except for vague phrases about the slow evolution of a civilized global society, they do not specify what should be done instead.

Similarly, Kernig's article on "Peace" (vol. 6, pp. 210-24) is an interesting and erudite study of the meaning which such terms as shalom, eirene, pax, fridu, and others have had in the cultures of the past. But it ends with the pre- 
posterous assertion that "the Western democracies are on the way towards creating . . . a world-wide peace system through increasing international economic integration" (ibid., p. 223), and also through their readiness to accept active and passive disarmament controls. He then uses this dubious assertion as an argument against disarmament efforts on the grounds that Soviet intransigence has frustrated all such efforts.

The pattern in these and other articles thus is the following: Solid scholarship and impressive erudition are embedded in a view of the world which idealizes the "West," regards the Communist camp as unreasonable and unyielding, and produces policy recommendations that take a tough cold war line reminiscent of the era of John Foster Dulles.

I was particularly disappointed by the article entitled "Intellectuals, Intelligentsia" (vol. 4, pp. 301-12). To begin with a petty criticism: its author does not seem to realize that late nineteenth-century Russian usage of the term "intelligentsia" is closely related to the connotations which "Die Intelligenz" had in early nineteenth-century Germany. The Russian term quite likely was an adaptation of the German one, not directly derived from Latin. More serious, the article offers confused definitions and an equally confused historical account. Its author makes fantastic generalizations about intellectuals in general, ascribing to them utopian leanings, radicalism, extremism, doctrinaire tendencies, and other shortcomings--as if professional intellectuals or people of high education had not espoused every possible manner of doctrine with every possible degree of intensity. Moreover, he lumps too many groups under the one heading of "intellectuals." The reader, therefore, frequently does not know about whom the author is writing. The section on "the intelligentsia and politics," as if to disprove assertions made about intellectuals earlier in the article, is nothing more than a survey of political attitudes, from extreme radical criticism through apologetics to total withdrawal, which anyone might take. "The intelligentsia reacts towards politics in three different ways: it criticizes the political system; it participates in it; or it retreats into its "ivory tower," he writes (ibid., p. 303) -as if this were not the option everyone has and exercises, whether intellectual or not, whether educated or not, except that the less educated might retreat into something else than an "ivory tower." I was struck by an undercurrent of hostility against intellectuals which the article expresses, not so much by stating it outright, but rather by citing judgments about the intelligentsia primarily from the writings of anti-intellectual critics, such as Barrès, Maurras, and Aron. What the reader takes home with him (whether the author intended this or not) is a know-nothing suspicion of intellectuals as irresponsible wordmongers. Indeed, the article expressly singles Western intellectuals out as the most vulnerable target for Communist propaganda (p. 305) and makes communism appear to be the conspiracy of intellectuals. Meanwhile it offers a ludicrous explanation of the role of the intelligentsia in socialist countries: Communist elites are so eager to increase the numbers of their intelligentsia that they make no attempts whatever to correlate the number of university graduates with the needs of the economy (p. 310)-a statement which every student of higher education in the USSR. and Eastern Europe will challenge.

In many ways, this article illustrates a failing which pervades much of the encyclopedia, and particularly the many articles by von Beyme and Kernig. 
Their writings are based on the conviction that communism is an ideology, that is, a mental delusion, while social studies in the "West" have now become scientific. Thus, in "Cold War" (vol. 2, pp. 27-42), Kernig asserts that the cold war, much historical evidence notwithstanding, has been different from all previous big-power clashes. It has been different because today, in crisis management, we (that is, the Western policymakers) proceed on the basis of rational planning, with scientific knowledge; whereas in previous times statesmen acted impulsively and on the basis of impressionistic knowledge or hunches (ibid., pp. 40-41). The implication that today we no longer make subjective judgments and irrational decisions seems to me to be unwarranted, to express it mildly. Moreover, in the face of the Cambodia "incursion," the Bay of Pigs landing, and similar recent events, Kernig has the audacity to say that today even the president of the United States no longer has the same freedom to make war that presidents still had in the immediate postwar period. This is a dig primarily aimed at Franklin Roosevelt, whom Kernig criticizes repeatedly for usurping power in the area of foreign policy and for making disastrous judgments and decisions (especially his efforts to bring the United States into World War II) that have weakened the "West." Roosevelt is consistently portrayed as a dupe of the Communists. Kernig obviously believes that scientific and rational crisis management in world affairs was developed only in the last two decades.

In a similar vein, von Beyme's article on "International Relations" (vol. 4, pp. 365-78) tells the reader that "unlike modern theories, older theories on international relations tended to be strongly motivated politically." The implicit assumption is that we now have the scientific truth. This assumption clearly underlies the entire confrontation enterprise of the Encyclopedia and makes it a caricature and mirror image of Soviet dogmatism. In perfect mimicry of Soviet political textbooks, the confrontational articles of the Encyclopedia convey the authors' deep conviction that all is well in the Western democracies, and particularly that we have reason to be satisfied with the achievements of our philosophy and social science, whereas the Communist world, deplorably as well as alarmingly, still succumbs to dangerous illusions. In order to support such assumptions, the confrontations often are structured so that comparisons are made between Communist or Soviet realities and Western ideals or Western rhetoric; or, again, between tough Soviet rhetoric and actual compromises made by the West. One need not be a Marxist or a Communist, one need not even be in sympathy with any aspect of life, politics, or ideology in the Communist world, to realize that such a blanket assumption of his own rectitude or of the selfevident virtues of his system is likely to make a writer look ridiculous, however solid his scholarship and however impressive his erudition. (I use the masculine form of the personal pronoun here because the proportion of women among the contributors to this encyclopedia is at most about 5 percent.)

Scattered through the Encyclopedia is a hard core of articles on cold war themes in which scholarly qualities have, by and large, been overwhelmed or crowded out entirely by ideological assumptions. In all of them, Western sanity, decency, flexibility, humaneness, and openness are contrasted with the delusions, intransigence, deviousness, and toughness of the Communist world. These articles abound with generalizations that any newspaper reader could readily 
refute; and some of them prescribe or suggest courses of action that seem to be suspect on pragmatic as well as moral grounds. Let me adduce a few examples.

"Free World" begins with a cautious critique of the term it discusses, but in the final analysis accepts it: "the free world has succeeded in establishing this characterization of itself" (vol. 4, p. 40) because of its ability to change under the blows of criticism and self-criticism. It seems to this reviewer that a propaganda term like "Free World," whatever the realities that make its use in political oratory justifiable, should have been omitted from a reference work that claims to be scholarly. It smacks too much of self-congratulation.

"Coexistence," writes Jean LaLoy, Paris, will be a sham until the Soviet Union "abandons its self-imposed mission to transform all human society." M. LaLoy writes as if he were unaware that his own views have been subjected to serious challenge by Western scholars. He reminds me of a priest whom I once heard give a lecture on the Christian-Marxist dialogue: he would be eager to engage in such dialogue, he argued, as soon as the Marxists stopped lying. According to LaLoy, the real obstacle to coexistence is not the difference in the social systems; "the real obstacle is Soviet messianism . . .," that is, the conviction of the Soviet leadership that their system is superior to all others in every respect (vol. 2, p. 26). He ends by exhorting the world to overcome the ambiguities of "peaceful coexistence" and to create institutions based on a stable balance between natural diversity and moral unity. Would "National in Form; Capitalist in Content" be the formula he has in mind?

"Guerilla Warfare" (vol. 4, pp. 99-119) begins with a comprehensive history which, in effect, is an impressive summary of the reasons why the United States could not have won in Southeast Asia. In part 2 of the article, Kernig inexplicably omits mentioning the many things (most of them negative) which Engels wrote about guerilla warfare. The main point he seems to be making has little to do with guerilla warfare, however: his basic message is that the West, having attained all its political aims, no longer has well-defined aims but only bickers about minor problems. "Human dignity seems to have been universally attained and human degradation to be universally impossible. In principle there is little left to strive for; what Western man has he hopes to keep for evermore" (ibid., p. 116). Further: "There are no more long-term objectives -they have all been reached" (ibid.). In contrast, the Communists do have aims, and those aims are utopian, or at least unattainable in the foreseeable future. Kernig then observes sadly that the Third World guerilla is incapable of understanding this and therefore listens to the Communists who denounce the Western imperialists and exploiters. Thus the Third World guerilla's belief that he is being exploited is a myth suggested to him by outside agitators. But because the Communist denunciations are untrue, we cannot deal with them by changing our relations with the Third World. Instead, we can only practice counterinsurgency; and his prescription for this could have come from the notebooks of Gordon Liddy: exercise tightest control over the native population; maintain one soldier for every 5-10 inhabitants ; plan for many years of military occupation (ibid., p. 117).

"Diplomacy" (vol. 2, pp. 438-50) offers a formalistic treatment of Western diplomatic structures and practices, followed by an essay on Soviet diplomacy which sadly observes that Soviet foreign relations are conducted not only by 
accredited diplomats but also by party, police, intelligence, armed forces, and other agencies-as if the CIA, USIA, USAID, USDOD, not to speak of ITT, GM, United Fruit, Aramco, and so forth, did not exist. This is a typical instance of the many comparisons between Western textbook myths and Soviet reality. Kernig adds that during the cold war Soviet diplomats spoke the offensive language of ideology and that their missions became accretions of propaganda activity. Does he seriously believe that this was not true of their Western counterparts? He then tackles the problem of explaining why the United States is both far more active and interventionist in global affairs than the Soviet Union and rather more impatient with the sovereignty claims of small nations. He explains this by arguing that Western diplomacy represents progressive internationalism while Soviet diplomacy, insisting on the strict interpretation of outdated, anachronistic principles of sovereignty, resorts to a disruptive sort of legalism. He also points at a conflict between the overt and the covert aspects of Soviet diplomacy, blaming the resulting contradictions on the rigidities of their unrealistic ideology. Senator Fulbright might be tempted to make similar statements about the foreign policies of the United States-something which Kernig does not, of course, acknowledge. As a result of this conflict between overt and covert activities, Kernig asserts, Soviet diplomacy is duplicitous, helpless, and self-defeating. Many specialists in the study of Soviet foreign policy would, of course, strongly disagree with him on this characterization of Soviet diplomacy. He ends with the remark that the contradictions could be overcome only if Soviet diplomats were truly given the task of conducting honest and realistic dealings with their Western counterparts, who, we must assume, are honest and realistic already. One ought to refer Professor Kernig to some recent American scholarship on foreign policy decision making in the United States.

In "Espionage" (vol. 3, pp. 215-19) a Mr. Erich Dethleffsen, identified only as a resident of Munich, contrasts the scruples of Western intelligence services with the unscrupulous behavior and disregard of diplomatic etiquette displayed by Soviet intelligence agencies. Obviously, there are several important events in the history of the postwar period about which $\mathrm{Mr}$. Dethleffsen has not yet heard. He calls Soviet intelligence agents ideological fanatics (which they might well be) and then praises their Western counterparts for identifying with the cause they serve. Is there a difference between these two attitudes, or is he merely giving a negative evaluation of the Soviet agents' loyalty to their cause while heartily approving of the ideological fanaticism on our side? He blandly states that intelligence services, except those in underdeveloped countries, do not make political decisions, but assumes that the Soviet services are listened to more attentively than their Western counterparts. He cites no evidence and, again, may not have heard about the Bay of Pigs invasion. The article ends with the assertion that intelligence services function as stabilizing agents in world politics-an interesting hypothesis for which I would like to see some supporting evidence.

"Anti-Communism" (vol. 1, pp. 128-32) has less to say about its purported subject matter than about the Soviet reaction to it, which the author calls hysterical. The article seeks to prove that the anti-Communist hysteria of the Western world was justified and sane, while the Soviet reaction to this hysteria was insane. To accomplish this, he debunks all Soviet fears of capitalist encirclement, 
including the threat represented by the Third Reich. The West is thus shown to have been sober and peaceful. The Soviet Union is depicted as paranoid, anticommunism being merely a figment of a lurid imagination. Then, as if to belie his entire argument, he suggests that we develop an updated anti-communism which should be made attractive to oppositionists within the Communist countries. Furthermore, he denounces, as crypto-Communists or as dupes of communism, all those who oppose the ideology of anti-communism: "Denunciation of its representatives as henchmen of reaction, vindictive emigrants, frustrated ex-communists and fellow-travelers only aids the communist cause" (ibid., p. 131). He explains the attitude of those who reject anti-communism as "due to lack of experience (e.g., among young people) and immature political insight" (ibid., p. 131), adds a large number of additional explanations, and concludes that "anti-anti-communism is the symptom of a deep-seated malaise and fear, but may also be the expression of superficial criticism of the present political and social order, the aggressiveness of which may be directed against anticommunism as a surrogate" (ibid., p. 132). The article is a blatant relic of the McCarthy era even if, in passing, it censures the late senator from Wisconsin for excesses. With its heavy style, including copious ironic use of quotation marks, it is a mirror image of Stalinism at its worst-dogmatic, smug, selfsatisfied, and semiliterate.

The article on "Cold War," to which Kernig contributed two sections, is perhaps the ideological heart of the entire encyclopedia. Here again Kernig contrasts the flexibility, adjustability, and resultant realism of Western, especially American, thinking with the falseness and inflexibility of Soviet ideology to which, he claims, the Soviet leadership is totally committed even though reality has increasingly shown it to be false. "The disparity between the developments in East and West with regard to the coordination of political theory and practices," he writes, "reveals what was genuinely new and incomparable in the unique conflict which is termed the cold war: whilst one world power-the USA -is already willing to draw the theoretical and practical consequences of the diminished degree of freedom of decision-making, the other world power-the USSR - tried to evade these consequences both in theory (that is, ideologically) and from case to case in practice" (vol. 2, p. 42). In his attempt to demonstrate the lethal hold which the delusion of ideology has over the Kremlin, Kernig develops a model of interplay between ideology and practice which is so involved that at times he writes like a scholastic trying to compute the number of angels on the point of a pin.

To be sure, the authors of this article have studied the cold war well. While their bibliography omits many significant works that have recently been written by the so-called revisionists, they do concede throughout that the cold war was caused by a mutually faulty assessment of the antagonist's motives and capabilities. Indeed, the original meaning of the term is identified as an expression of American hostility toward the Soviet Union. Yet the entire phenomenon is defined as a conflict of power and ideologies between communism and a world that sees itself as free and democratic. The Western self-image is never challenged, but Soviet theories about the cold war are labeled as ideological and propagandistic, and the Soviet side is condemned for "judging Western statements on this subject exclusively from the point of view of its own camp" (ibid., p. 29). 
Though the authors are well aware of the abruptness with which United States attitudes and policies toward the USSR changed after the end of World War II, they say nothing about the impact these changes had in Moscow. They make passing references to the caution and conservatism of Stalin's foreign policy, but do not incorporate these findings into their explanations. They correctly identify the "hard line" of American foreign policy as an indirect attack on the New Deal ; and their repeated expressions of aversion to Roosevelt lead me to assume that they consider this attack justified. They also trace numerous cold war activities sponsored by the United States as well as the development of a cold war ideology in the West. Yet they assert that it was only Soviet aggressiveness which "forced the West into a defensive position," and the genesis of the cold war is treated as, at most, an excusable error of judgment in Washington. Opposition to the cold war, meanwhile, is characterized as a service rendered to Soviet foreign policy. Moreover, Kernig asserts that the term "cold warrior" has lost all meaning, if only because Soviet writers use it to label anyone who is anti-Soviet. In short, the article is a muddle of contradictions, showing that its authors have fallen victims to the very same ideological confusion they attribute to their Soviet colleagues. In the analytic sections it is surprisingly vague and abstract. No powers are named, no events are cited. It is as if the authors were afraid to reveal all they knew about what really happened.

In this hard core of cold war pieces we have, it seems to me, the basic purpose of the Encyclopedia. It is not a worthy purpose; and those who serve it must sacrifice part of their scholarly integrity for it. Again, this does not deny the high level of scholarship on which many articles in this work have been written, and the entire Encyclopedia demonstrates that broad knowledge and brilliant insight can coexist quite nicely with blatant political bias. But the obvious intrusion of this bias into some of the core articles of the work limits the usefulness of these volumes and makes the whole enterprise suspect. 